\title{
Functional Performance from the Perspective of Building Management Team
}

\author{
Hasnizan Aksah, Md Najib Ibrahim, \\ Elma Dewiyana Ismail, Siti Hajar Rahim \\ Faculty of Architechture, Planning and Surveying, \\ Universiti Teknologi MARA, 40450 Shah Alam, Malaysia \\ hasnizan@salam.uitm.edu.my
}

\begin{abstract}
Maintaining the functional performance of historical buildings is challenging. This study seeks to understand the perceptions of building management team towards the functional performance of postoccupancy evaluation. A semi-structured interview was conducted with 24 respondents from building management team. The study found that the three highest criteria for the score of importance and applicability were comfort, safety and services. This study will benefit professionals and participants in the industry who have the interest in improving functional performance in building management of historical government building.

Keywords: Building Management Team; Historical Government Building; Post Occupancy Evaluation ; Functional Performance

elSSN: 2398-4279 @ 2016. The Authors. Published for AMER ABRA by e-International Publishing House, Ltd., UK. This is an open access article under the CC BY-NC-ND license (http://creativecommons.org/licenses/by-ncnd/4.0/). Peer-review under responsibility of AMER (Association of Malaysian Environment-Behaviour Researchers), ABRA (Association of Behavioural Researchers on Asians) and cE-Bs (Centre for EnvironmentBehaviour Studies), Faculty of Architecture, Planning \& Surveying, UniversitiTeknologi MARA, Malaysia.

https://doi.org/10.21834/ajqol.v1i4.14
\end{abstract}




\subsection{Introduction}

Historical building is a building that has outstanding universal value from the point of view of historic, art or science in their architecture, homogeneity or their place in the landscape (National Heritage Act, 2005). Therefore, historical building deserves to have extra care and attention so that it can live longer for the future generations to gain as much knowledge from the history and for them to gain the sense of identity and continuity from it. Building management team are the team that supervises the building maintenance, services and others relating to the facility operation to ensure the building perform as intended.

But, maintaining the functional performance of historical buildings is challenging. In line with conservation principles, any works should keep as much as possible the original building structure and fabric (Siti, 2011). Building owners or managements are not allowed to modify the structure of building when they are growing or expanding, and the building does not provide the kind of development they seek. In addition to that, modern services cannot be installed without taking the risk of affecting their structural integrity (Raha, Syahrul, Rao, \& Pitt, 2011). However, due to lack of technical knowledge, most of the conservation refurbishment work carried out using improper and inconsistent techniques which result in poor interior and exterior of the buildings (Kamarul et al., 2008; Syahrul, Emma, Pitt, \& Zuraidah, 2010). On top of that, the maintenance works is still lacking and primarily carried out on an ad-hoc basis without proper maintenance specifications (Robiah \& A.Ghafar, 2011). The next issue is inadequate fire safety management in buildings due to the absence of guidelines for historical building (Salleh, Ahmad, 2009). Finally, the maintenance cost of historical buildings is high, and it constitute to an enormous amount of total cost (Syahrul, Emma, \& Aiman, 2011).

Meanwhile, Post Occupancy Evaluation (POE) is the systematic process of evaluating building after they have been built and occupied for some time. The purpose of POE is to identify the problems in buildings and enhance the building performance in many aspects including the process, functional and technical performance. This study seeks to understand the perceptions of building management team towards the functional performance of post occupancy evaluation. The objective of this study is to determine the importance and applicability of functional performance criteria in a post occupancy evaluation of historical government buildings from the perspective of building management team. The second objective is to identify the challenges in achieving the functional performance criteria.

\subsection{Literature Review}

Historical buildings provide us the sense of wonder and make us want to know more regarding the culture produced by them (Arazi, Faris, \& Mahmoud, 2010). But, most of the historical government buildings in Malaysia have deteriorated; that is the physical quality of the building is slowly declining, and the building is not performing the way it was intended to. These buildings have been underutilized, wrongly used or dilapidated. These issues 
exert pressures on both public or private building owners and occupants to maintain their buildings to keep the good condition of the building.

Meanwhile, POE is a systematic evaluation tool that seeks to evaluate the performance of an occupied building with the intention to achieve continuous building performance improvement (Neo et. al, 2014). POE reflects on how the building meets user needs by addressing the issues that may enhance user performance, satisfaction and productivity (Preiser et al., 2005). POE is a method of providing feedback from users and experts to improve planning, activities and also the performance of the building throughout its life cycle (Meir, Garb, Jiao, \& Cicelsky, 2009; Blyth \& Gilby, 2006).

Functional performance is one of the elements of POE that can assist designers and building managers to design future refurbished historical building that can enhance users' satisfaction level (Hasnizan, Ahmad, Elma, \& Zarina, 2014). Functional performance evaluation looks into how the building supports the institution's goals and how well the users' needs are supported (Blyth et al., 2006). Functional performance also concerns the relationship of the building with its occupiers and embraces issues such as space, layout, ergonomics, image, ambience, communication, health and safety, and flexibility (Yasin and Egbu, n.d). POE is essential in building performance evaluation as a technique to evaluate whether the building meets the user's requirements in terms of functional performance (Ahmad, Hasnizan, \& Shahrul, 2012). There are eight (8) criteria of functional performance, and the criteria are; space, aesthetics value, comfort, amenity, services, safety, operational management and life-cycle cost (Hasnizan, Ahmad, Elma, \& Zarina, 2014).

\subsection{Methodology}

This research utilised a semi-structured interview. This interview verifies information obtained as well as reveal information not available through the literature reviews. The interview checklist was constructed with two (2) parts. For part A, the questions were based on four-point Likert scale (very unimportant, unimportant, important, very important) for the score of importance and (do not apply, apply seldomly, apply moderately, apply greatly) for the score of applicability that requires the respondents to rate the both scores. For Part $B$, it required respondents to give their opinion on challenges in achieving eight (8) functional performance criteria of historical government buildings. A total number of 24 questionnaires were distributed to respondents who were the historical building management team. The score of importance was analysed by mean and mode values to identify the most important criteria and the most unimportance criteria. The score of applicability also was analysed by mean and mode values to identify the most applicable and the inapplicable criteria applied by building management team. Meanwhile, the challenges in achieving the functional performance criteria of post occupancy evaluation of historical government buildings formed a database for open-ended questions analysis. The question were analysed based on the percentage formula as shown in Formula as below: 


$$
\text { Percentage, } \%=\frac{\text { No. } . \text { f Responses }}{\text { Total Number of Responses }} \times 100
$$

\subsection{Results And Discussions}

\subsection{Score of Importance}

Table 1 shows the score of importance of functional performance criteria. Comfort (3.83), Safety (3.83) and Services (3.79) are the three most important criteria from the perspective of building management team. Comfort is important because most of the buildings are now used as an office building. Occupant comfort affects productivity (Syahrul et al., 2010). Equally important is the safety of the workers which is legally required, for example by Occupational Safety and Health Act 1994. The next is services. Without building services, their activities might be delayed thus decrease their productivity.

Table 1: Mean and mode values for the score of importance

\begin{tabular}{llcc}
\hline Criteria & Mean & Mode & Rank \\
\hline Comfort & 3.83 & 4 & 1 \\
Safety & 3.83 & 4 & 1 \\
Services & 3.79 & 4 & 2 \\
Aesthetic and Image Value & 3.71 & 4 & 3 \\
Life-Cycle Cost & 3.67 & 4 & 4 \\
Space & 3.58 & 4 & 5 \\
Amenity & 3.54 & 4 & 6 \\
Operational management & 3.50 & 4 & 7 \\
\hline
\end{tabular}

\subsection{Score of Applicability}

Table 2 shows the score of applicability of functional performance criteria. Services (3.58), Safety (3.58) and Comfort (3.50) are the three most important criteria from the perspective of building management team. The services are crucial in office building because it support the workers' daily activities to ensure the productivity. Equally important is the safety of the workers. As stated earlier, safety is legally required. The next is Comfort that directly affects productivity.

Table 2: Mean and mode values for the score of applicability

\begin{tabular}{lccc}
\hline Criteria & Mean & Mode & Rank \\
\hline Services & 3.58 & 4 & 1 \\
Safety & 3.58 & 4 & 1 \\
Comfort & 3.50 & 3 & 2 \\
Life-Cycle Cost & 3.42 & 4 & 3 \\
Aesthetic and Image value & 3.42 & 3 & 4 \\
Operational management & 3.42 & 3 & 4 \\
Space & 3.29 & 3 & 5 \\
Amenity & 3.17 & 4 & 6 \\
\hline
\end{tabular}




\subsection{Challenges in achieving functional performance criteria on the historical government buildings}

Table 3 shows the challenges in achieving functional performance criteria. The building management team ranks the three highest issues as Aesthetic and Image Value, Life Cycle Cost and Amenity. Maintaining the aesthetic and image value is hard according to the respondents especially the maintenance work that might affect the building integrity because it needs to get approval from many parties such as the owner, the local authorities, and also from the National Heritage Department. Furthermore, to obtain the material which is the same or similar as original is difficult (Siti, 2011). Moreover, lack of technical knowledge of workers regarding refurbishment of historical building also affecting the integrity of historical building (Kamarul et al., 2008). The next challenge is Life Cycle Cost particularly the insufficient budget allocation that will limit the work of operating, replacement, alteration and also the work of maintenance in the historical building. In general, the maintenance cost is extremely high because they carried out based on ad-hoc basis.. On top of that, the historical building requires extra and special care that needs additional cost. The other challenge is to adapt new amenity in the historical building such as the parking area, staff lounge and specific requirement for disabled person. The fact that historical building cannot be changed structurally has resulted in difficulty to adapt new amenity to suit the disable person's need.

Table 3. Challenges in achieving functional performance criteria on the historical government buildings

\begin{tabular}{|c|c|c|c|}
\hline Criteria & Challenges & Percentage \% & Rank \\
\hline \multirow[t]{3}{*}{ Space } & $\begin{array}{l}\text { Complying legal } \\
\text { requirement }\end{array}$ & 5 & 5 \\
\hline & Limited space & 5 & 5 \\
\hline & $\begin{array}{l}\text { Planning in respect of end } \\
\text { user }\end{array}$ & 3 & 6 \\
\hline \multirow[t]{2}{*}{$\begin{array}{l}\text { Aesthetic and } \\
\text { Image Value }\end{array}$} & $\begin{array}{l}\text { Interruption of new design } \\
\text { extension }\end{array}$ & 2 & 7 \\
\hline & $\begin{array}{l}\text { Maintaining the aesthetic } \\
\text { and image value }\end{array}$ & 16 & 1 \\
\hline \multirow[t]{3}{*}{ Comfort } & $\begin{array}{l}\text { Adaptation to the latest } \\
\text { technology }\end{array}$ & 2 & 7 \\
\hline & Lack of monitoring & 7 & 4 \\
\hline & Noise & 1 & 8 \\
\hline \multirow[t]{2}{*}{ Amenity } & Adaptation of new amenity & 11 & 3 \\
\hline & Disabled person & 1 & 8 \\
\hline \multirow[t]{3}{*}{ Services } & $\begin{array}{l}\text { Difficulty in maintenance } \\
\text { works }\end{array}$ & 7 & 4 \\
\hline & $\begin{array}{l}\text { Installation of modern } \\
\text { services }\end{array}$ & 2 & 7 \\
\hline & Vandalism & 1 & 8 \\
\hline Safety & $\begin{array}{l}\text { Building material prone to } \\
\text { fire }\end{array}$ & 1 & 8 \\
\hline
\end{tabular}




\begin{tabular}{llcc} 
& $\begin{array}{l}\text { Negative effect of materials } \\
\text { Structural defects } \\
\text { Upgrading the safety } \\
\text { equipment }\end{array}$ & 1 & 8 \\
\hline $\begin{array}{l}\text { Operational } \\
\text { management }\end{array}$ & Lack of knowledge & 11 & 8 \\
\hline Life cycle cost & $\begin{array}{l}\text { Insufficient budget } \\
\text { allocation }\end{array}$ & 7 & 4 \\
& $\begin{array}{l}\text { Lack of knowledge } \\
\text { Maintenance cost }\end{array}$ & 1 & 6 \\
\hline
\end{tabular}

\subsection{Conclusion}

To conclude, the three main criteria for both scores of importance and applicability are the comfort, safety and services. These criteria are important because they relate closely with the occupants comfortability and their productivity. On the other hand, the first rank of total challenges is the maintaining the aesthetic and image value. The building management teams find it is difficult to maintain such architectural building that rules by stringent regulations. The second rank is the maintenance cost that is extremely high due to the special care those buildings require. Nevertheless, the third on the ranking are the adaptation of new amenity and upgrading the safety equipment. These two issues relate closely with the regulations by the relevant acts, National Heritage Department and also Fire Department. On the contrary, the lowest ranking of challenges of functional performance criteria are noise, amenity for disabled person, vandalism, unsusceptible building material towards fire, negative effects of building materials, structural defects and last but not least the lack of knowledge in estimating the life-cycle cost. As a conclusion, $\mathrm{POE}$ is a rigorous evaluation method of identifying problems in building to determine the success and failure of a building. From the findings, it shows that POE is appropriate to determine the importance, applicability, and challenges in achieving functional performance criteria on historical building as well as providing the recommendation to reduce the challenges and improve the building performance.

\section{Acknowledgement}

The Authors would like to acknowledge and extend heartfelt gratitude to the Ministry of Higher Education (MOHE) and Research Management Centre of Universiti Teknologi Mara for supporting this research under Research Acculturation Grant Scheme (RAGS) (600RMI/RAGS/5/3/ (195/2013). 


\section{References}

Ahmad, E.H., Hasnizan, A., \& Shahrul, Y. (2012). Functional assessment through post occupancy review on refurbished historical public building in Kuala Lumpur. Procedia - Social and Behavioral Sciences, 68, 2012, 330340.

Blyth. A., \& Gilby. A. (2006). Guide to post occupancy evaluation. Retrieved from http://www.smg.ac.uk/documents/POEBrochureFinal06.pdf

English Heritage. (2004). Easy Access to Historic Buildings. London : English Heritage.

Hasnizan, A., Ahmad, E. H., Elma, D. I., Zarina, I. (2014). Criteria Overview for Functional Performance Evaluation pertaining to Refurbished Historical Building, Proceedings of the Colloquium on the Administrative Science and Technology. Kuching, Sarawak.

Kamarul, S. K., Lilawati, A. W., \& Ghafar, A. (2008). Pilot survey on the conservation of historical buildings in Malaysia. Retrieved from

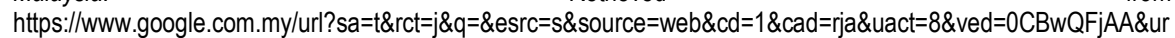
I=http \%3A\%2F\%2Feprints.usm.my\%2F25151\%2F1\%2FARCHITECTURE_AND_URBAN_DESIGN_1.pdf\&ei=77A PVbvGKs_kuQSd0IDoCA\&usg=AFQjCNG3FxIf7yQIIX2ICkjea04MLp3RZw\&sig2=_loJRN7

Laws of Malaysia. (2006). Act 645: National Heritage Act 2005. Malaysia: The Commissioner of Law Revision.

Meir, I. A., Garb, Y., Jiao, D., \& Cicelsky, A. (2009). Post-occupancy evaluation: An inevitable step toward sustainability. Advances in Building Energy Research, 3, 189-220.

Mohd F. M Y, Egbu, C. (nd). Harnessing Knowledge Management In The Process of Performance Evaluation of Facilities in Malaysia: A Critical Success Factors. Retrieved on May, 25,2015 from http://usir.salford.ac.uk/12824/1/1384_-_fadil.pdf

Neo, B. W., Izran, S.M., Maizan, B., Janice, L, Y, M, Nurul, N. Z. \& Abdul, Q. N. (2014). Critical Success Factors for Post Occupancy Evaluation of Hospital Building Performance. Jurnal Teknologi, 71:4, 161-166. Retrieved on June 5, 2015 from www.jurnalteknologi.utm.my

Preiser, W. F., \& Vischer, J. (2005). Assessing Building Performance. Butterworth Heinmann: Elsevier

Raha, S., Syahrul, N. K., Rao, S. P., \& Pitt, M. (2011). The environmental performance of air conditioning systems in heritage buildings in tropical climates. Journal of Surveying, Construction \& Property , 2, 1, 93-106.

Robiah, A.R, A.Ghafar, A, (2011). Overview of Maintenance Approaches of Historical Buildings in Kuala Lumpur A Current Practice The 2nd International Building Control Conference 2011.Procedia Engineering Volume 20, 2011, Pages 425-434.

Salleh, N. H., \& Ahmad. A. G. (2009). Fire safety management in heritage buildings: The current scenario in Malaysia. 22nd CIPA Symposium. Kyoto, Japan. Retrieved November 4, 2014, from $\mathrm{https}: / / w w w . g o o g l e . c o m . m y / u r l$ sa $=t \& r c t=j \& q=\&$ esrc=s\&source= web\&cd=2\&cad=rja\&uact=8\&ved=0CCcQFjAB\&url=http\%3A\%2F\%2Fcipa.icomos.org $\% 2 F$ fileadmin $\% 2$ Ftemplate $\%$ 2Fdoc\%2FKYOTO\%2F11.pdf\&ei=jgihVLWzNoOTuASe64DICQ\&usg=AFQjCNFatm0IWKrT0jBalXoS2QJcXUzCB w\&sig2=7Mt9gb68d4evT2I_Q8h2OA\&bvm=bv.82001339,d.c2E 
Siti, N. H. (2011). Heritage Building Conservation in Malaysia. Retrieved October, 13, 2014 from http://kotacity.blogspot.com/2011/04/heritage-building-conservation-in.html

Syahrul, N. K., Emma, A. Z., Pitt, M., \& Zuraidah, M. D. (2010). Occupant feedback on indoor environmental quality in refurbished historic buildings. International Journal of Physical Sciences , 5, 3, 192-199.

Syahrul, N. K., Emma, A. Z., \& Aiman, O. (2011). Preliminary evaluation of problems involved in maintaining heritage buildings in Malaysia. The Professional Journal of The Institution of Surveyors, 40, 1. 